\title{
Scalability of a Time- and Cost Effective \\ Procedure for the Synthesis of Picryl Bromide
}

Thomas M. Klapötke* and Dominik E. Dosch

Energetic Materials Research, Department of Chemistry, Ludwig-Maximilian University Munich, Butenandtstr. 5-13 (D), 81377 Munich, Germany 
1. ${ }^{1} \mathrm{H},{ }^{13} \mathrm{C}$ and ${ }^{14} \mathrm{~N}$ NMR data of (1)
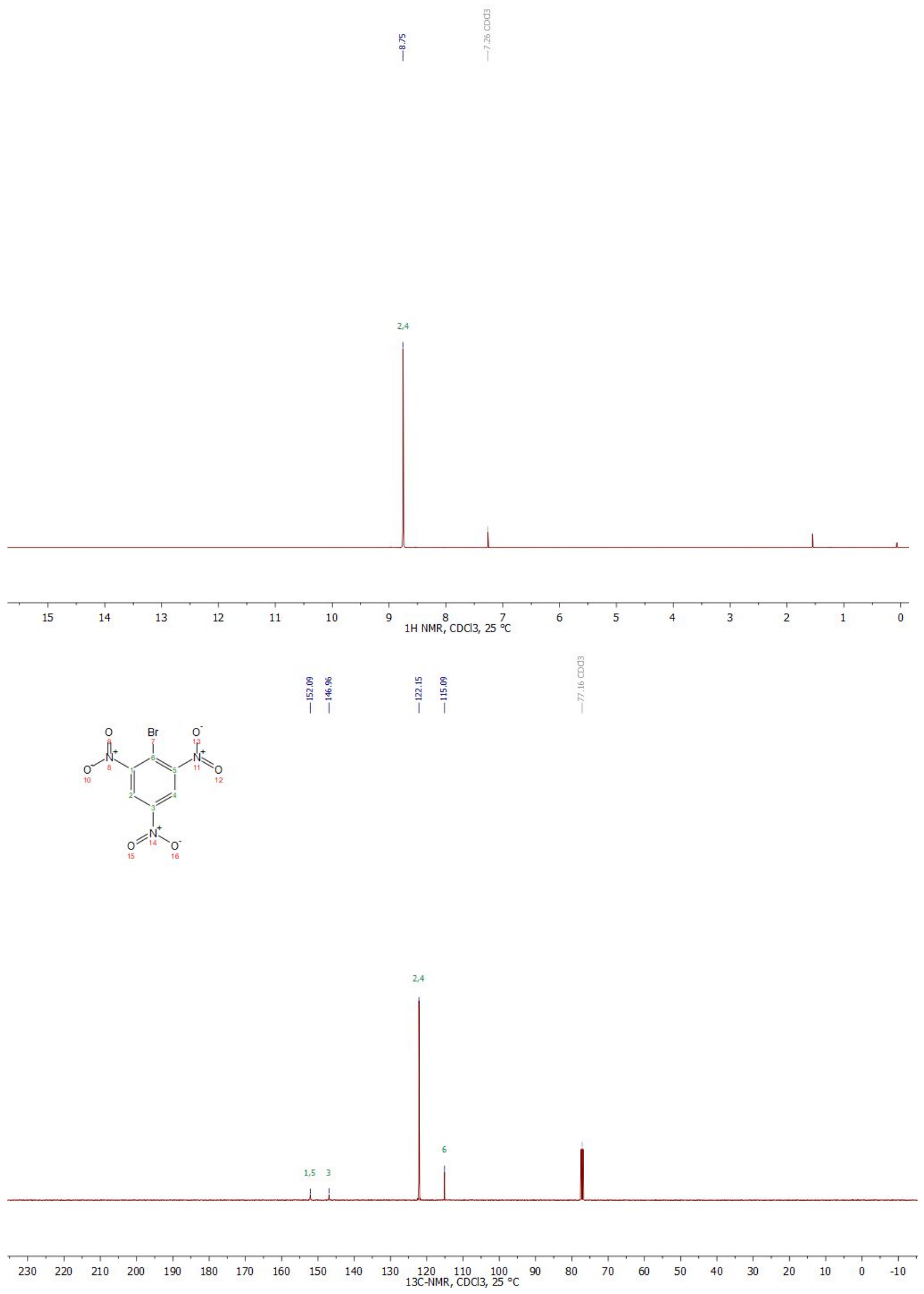
<smiles>O=C([O-])c1cc([N+](=O)[O-])cc([N+](=O)[O-])c1Br</smiles>

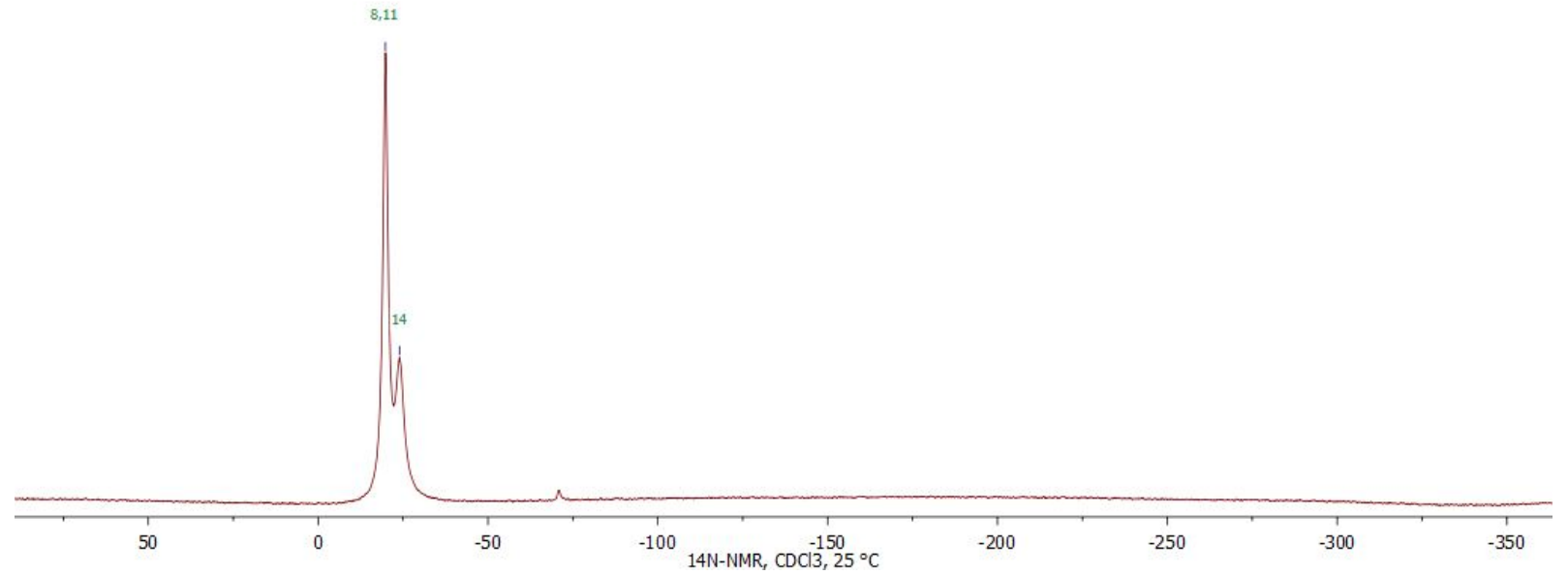

